https://doi.org/10.46344/JBINO.2020.v09i05.31

\title{
ALTERATIONS IN ANTI-OXIDANT AND SERUM LIPID PROFILE IN ADMINISTRATION OF METHANOL EXTRACT OF DENNETTIA TRIPETALA ON DIABETIC MICE
}

\author{
'M. A. Omoirri., 2 S. E. Iloh., ${ }^{2 N}$. U. Madubogwu., II. F. Ajegi and 3V. I. Eje
}

'Department of Pharmacology and Toxicology, Faculty of Pharmaceutical Sciences, Nnamdi Azikiwe University, Akwa, Anambra State, Nigeria

${ }^{2}$ Department of Pharmacology and Toxicology, Chukwuemeka Odumegwu Ojukwu University, Igbariam, Anambra State, Nigeria 3Department of human physiology faculty of Basic medical sciences, Bingham University Nassarawa state, Nigeria

Email: moscoly15@gmail.com osgiedeprof@yahoo.com

\begin{abstract}
In in-vivo experiments, one of the fastest killers of metabolic processes is prolonged accumulation of free radicals, which are often accomplices of lipid peroxidation reactions. In this wise, though numerous studies have advocated its managements with anti-oxidants, research on antioxidants from herbal source remain inconclusive. Thus, current study determined the anti-antioxidant and lipid lowering tendencies of methanol leaf extract of Dennettia tripetala on alloxan induced diabetic mice. Sixty five (65) mice were procured and randomly assigned into thirteen (13) groups of five mice each. Following period of acclimatization ( 2 weeks), animals were fed with various treatment as follows; Group 1 (normal control), group 2 (diabetic control), group 3 (received $5 \mathrm{mg} / \mathrm{kg}$ of Glibenclamide, a known anti-diabetic agent) and groups $4-13$ were given 250 and 500 $\mathrm{mg} / \mathrm{kg}$ doses of Methanol Extract [ME], N-Hexane Fraction [NH], Ethyl Acetate Fraction [EAF], Butanol [BF] and Water [WF] Fractions respectively. At the end of six (6) weeks treatment period, animals were subjected to overnight fast, with Fasting blood glucose (FBG) levels obtained by means of a glucometer, serum lipid profile levels were assayed (using a spectrophotometer) after obtaining blood samples by cardiac puncture. In the end, obtained data were subjected to statistical comparisons of mean differences, using the one way analysis of variance (ANOVA). Study observed a statistically significant decrease $(p<0.05)$ in FBG levels of extract treated group [ME] within 10 hours of acute treatment and 14 days short term treatment. Also, Administration of various treatments evoked a significant decrease $(p<0.05)$ in serum levels of total cholesterol, triglyceride and low density lipoproteins, with a preponderant significant elevation $(p<0.05)$ of high density lipoprotein (HDL-cholesterol) levels when compared with diabetic control.
\end{abstract}

Keywords: Anti-Oxidant, Lipoproteins, Lipid profile, Dennettia tripetala 


\section{INTRODUCTION}

The body is constantly exposed to the negative and sometimes lethal effects of oxidants during normal physiological processes. On a daily basis, up to $5 \%$ of inhaled oxygen may be converted to reactive oxygen species (ROS). These ROS have the ability to bind to cellular structures, such as deoxyribonucleic acid (DNA), ribonucleic acid (RNA), proteins and the cell membrane [1]. The damage is cumulative and may be the trigger for diseases such as arteriosclerosis, cancer and even Parkinson's disease in man [2].

To help curtail the menace due to free radical damage, antioxidants need to be supplied via normal dietary intake. This includes compounds such as vitamin A, C, E, carotenoids and the polyphenols, that is, phytogenic compounds abundant [with a higher bioavailability and therefore higher protective efficacy than synthetic antioxidants] within fruits and vegetables [3]. In addition to this ability to neutralize harmful oxidative reactants, the antioxidants may also be protective against neoplastic growth and proliferation, via other mechanisms.

Medicinal plants have been of great usefulness as alternatives to synthetic anti- diabetics, anti-oxidant, and in lipid lowering. Studies had shown that plants are used in the management of serum lipoprotein and glucose levels. For this reason, exploration of these properties in Dennettia tripetala would be an avenue for the development of natural molecules of herbal sources for managing ailments related to lipid peroxidation with huge spike in serum levels of free radicals.

Dennettia tripetala, also known as pepper fruit tree belongs to the Annonaceae family, a tree that grows up to $30 \mathrm{~m}$ high and often shrubby [4]. It is a tropical plant that is mostly dominant in the West African region especially Nigeria, Ivory Coast and Cameroon. It is locally called "Nkarika" in Calabar, ako in Edo, opipi in Idoma, omako Imako by the Niger Deltans and Urhobo/Isoko, nkarika in Ibibio, mmimi in Igbo and ata igbere in Yoruba. The young leaves and fruits have instinctive spicy taste with a characteristic aroma and fragrance [5]. It is a pungent, pepperish, spicy medicinal plant that is characterised by greenish appearance when unripe but tends to be reddish or pinkish in colour when ripe. Pepper fruit tree thrives mainly in the Savannah and rainforest zones while the fruit usually ripens between April and May [6]. The fruit is edible and rich in vitamin $C$. The leaves are used in folk medicine by some communities in parts of Southern Nigeria for the treatment of fever, cough, asthma catarrh, diarrhea and rheumatism. The leaves and roots are also commonly used by the local herbalist in folk medicine in combination with other medicinal plants to treat various ailment including fever, infantile convulsion, typhoid, worm infestation, vomiting and stomach upset [7]. The leaf extract had been demonstrated to possess antimicrobial activity against staphylococcus aureus [7], anti-nociceptive and anti- 
inflammatory activities, antioxidant and antimicrobial activities. The essential oil of D. tripetala fruits has been found to possess analgesic effects. The oil also relieved inflammation in rodents [8]. Pepper fruit has antinociceptive effects and as such can be used for reducing sensitivity to painful stimuli [8]. The essential oil and phenolic acid extract inhibit the growth of foodborne microorganisms such as Staphyloccocus aureus, Salmonella sp., Escherichia coli [9]. This point a role for pepper fruit in the preservation of food substances such as meat which is prone to rapid decomposition. The leaves were found to be effective in inhibiting the growth of the rot-causing fungus Sclerotium rolfsii in cocoyam both in vitro and in vivo [10]. Several other reports showed the antimicrobial activity of $D$. tripetala [7\&8].

Anosike et al., (2016) evaluated the anti-ulcer ability of ethanol extract from pepper fruit seed extract. Their findings showed that the ethanol extract of pepper fruit seed have potent and dosedependent anti-ulcer effect against aspirin-induced ulcer. According to these researchers, this anti-ulcer effect of pepper fruit can be attributed to its flavonoid content.

\section{Aim of Study}

Current study evaluated the antioxidant and lipid lowering properties of Dennettia tripetala extract on alloxan induced diabetic mice. Specifically, study determined the effect of different fractions of Dennettia tripetala on lipid profile level and body weight. Study also investigated the in-vivo free-radical scavenging (antioxidant) effect of various fractions of Dennettia tripetala on diabetic mice.

\section{Materials and Method}

\section{Study Design:}

Sixty five (65) mice were procured and randomly grouped into thirteen (13) of five mice per group as follows;

\begin{tabular}{|c|c|c|c|}
\hline Groups & Mice Condition & Treatments & Dose $(\mathrm{Mg} / \mathbf{K g})$ \\
\hline Group 1 & Normal control & $5 \%$ Tween 80 & \\
\hline Group 2 & $\begin{array}{l}\text { Negative } \\
\text { Control (Diabetic) }\end{array}$ & $5 \%$ Tween 80 & \\
\hline Group 3 & $\begin{array}{l}\text { Positive Control (Diabetic } \\
\text { Treated) }\end{array}$ & Glibenclamide & $5 \mathrm{mg} / \mathrm{kg}$ \\
\hline Group 4 & Diabetic & Methanol Crude Extract & $250 \mathrm{mg} / \mathrm{kg}$ \\
\hline Group 5 & Diabetic & Methanol Crude Extract & $500 \mathrm{mg} / \mathrm{kg}$ \\
\hline Group 6 & Diabetic & Ethyl Acetate Fraction & $250 \mathrm{mg} / \mathrm{kg}$ \\
\hline Group 7 & Diabetic & Ethyl Acetate Fraction & $500 \mathrm{mg} / \mathrm{kg}$ \\
\hline Group 8 & Diabetic & N-hexane Fraction & $250 \mathrm{mg} / \mathrm{kg}$ \\
\hline
\end{tabular}




\begin{tabular}{llll}
\hline Group 9 & Diabetic & N-hexane Fraction & $500 \mathrm{mg} / \mathrm{kg}$ \\
Group 10 & Diabetic & Butanol Fraction & $250 \mathrm{mg} / \mathrm{kg}$ \\
Group 11 & Diabetic & Butanol Fraction & $500 \mathrm{mg} / \mathrm{kg}$ \\
Group 12 & Diabetic & Aqueous Fraction & $250 \mathrm{mg} / \mathrm{kg}$ \\
Group 13 & Diabetic & Aqueous Fraction & $500 \mathrm{mg} / \mathrm{kg}$ \\
\hline
\end{tabular}

\section{Animals:}

A total of 100 male albino mice of between 18-35g were procured from the Laboratory Animal Facility of the Department of Veterinary Physiology and Pharmacology, University of Nigeria, Nsukka. Animals were then housed in wooden cages with full access to portable water and standard feed ad libitum, following which they were acclimatized for two weeks in compliance with guidelines from the National Institute of Health on the care and handling of laboratory animals.

\section{Collection and Authentication of Plant Materials}

Fresh Denettia tripetala leafs were obtained from Irri town, somewhere in Isoko South Local Government Area of Delta State, Nigeria; following which it was authenticated by an expert Taxonomist from the Department of Botany, Nnamdi Azikiwe University, Awka. A voucher number of PCG/UNIZIK/0631 was issued just after identification.

\section{Preparation of Plant Extract}

Fresh leaves of $D$. tripetala were washed in a running tap to remove dust and other debris, and air dried for two weeks. Dried leaves of Dennettia tripetala were pulverized with electrical blender and kept in clean air tight amber bottle. $750 \mathrm{~g}$ of the powdered material was cold macerated in $80 \%$ ethanol. The mixture was agitated continually for two days (48 hours). The filtrate was recovered and concentrated to dryness using water bath at $40^{\circ} \mathrm{C}$. The extract was stored in a refrigerator before use. The percentage yield of the extract was calculated using the following formula.

\section{$\%$ yield $=\underline{\text { Mass of Dry Extract }} \times \underline{100}$ Weight after extraction}

\section{Fractionation of methanol crude extract}

Fractionation was carried out using $\mathrm{N}$ hexane, Ethyl Acetate and Butanol following the method described by Ihekwereme et al., (2016). One hundred grams of crude extractwas dispersed in $500 \mathrm{ml}$ of distilled water then poured inside a separating funnel. N-hexane $500 \mathrm{ml}$ was added to funnel and shake thoroughly to mix. The mixture was allowed to separate into two distinct layers. The n-hexane portion, lupper layer) was separated and the other portion was subjected to fresh n-hexane until the n-haxane portion was clear completely. After the n-hexane phase, the other portion was subjected to ethyl 
acetate and butanol successively using the same process as described for $n$ hexane. The various fractions were filtered and concentrated to dryness using water bath set at $40^{\circ} \mathrm{C}$. The fractions were stored in a refrigerator before use [11].

\section{$\mathrm{LD}_{50}$ Determination}

Acute toxicity, LD50 test was carried out using the method of Lorke (1983) [8]. A total of 13 mice, weighing 28-30g were used in the two phases. In the first stage, the animals were divided into 3 groups of 3 mice each, and the extract was administered at three dose level $(10,100$ and $1000 \mathrm{mg} / \mathrm{kg}$ ) body weight. The animals were then monitored for 24 hours. Absence of deaths in the first phase led to the use of 2000,3000, 4000 and 5000 $\mathrm{mg} / \mathrm{kg}$ dose of extract for 4 groups of 1 animal each. Animals were examined again for another 24 hours. The number of death (s) was noted for each group and the LD50 was calculated as follows;

$L_{50}=\sqrt{ }\left(D_{0} \times D_{100}\right)$.

Where: $D_{0}=$ Highest dose that gave no mortality

$$
D_{100}=\text { Lowest dose that produced }
$$
mortality.

\section{Yields of extract and fractions}

The methanol leaf extract of $D$. tripetala was dark green in colour after concentration to dryness. Two hundred gram $(26.67 \% \mathrm{w} / \mathrm{w})$ of extract was recovered from powdered leaves of 750 g. Weight of fractions and their yields calculated from $100 \mathrm{~g}$ of the crude extract are: n-hexane fraction (24 g, 25\% $w / w)$, ethyl acetate fraction (28 g, 30\% $\mathrm{w} / \mathrm{w})$, butanol fraction $(21 \mathrm{~g}, 21 \% \mathrm{w} / \mathrm{w})$, water fraction (18 $\mathrm{g}, 19 \% \mathrm{w} / \mathrm{w})$.

\section{Dosage selection:}

Dosage of extract administered to animals was determined from $1 / 10^{\text {th }}$ and $1 / 20^{\text {th }}$ of the estimated LD50 as described by Neharkar and Galkwad (2011) [13]

\section{Biochemical Assays}

\section{Determination of serum total cholesterol}

Serum total cholesterol (TC) was evaluated using Randox commercial assay kits following the methods described by Ezeigbo, (2016). One millilitre $(1 \mathrm{ml})$ of the working cholesterol reagent was added into tubes labelled blank, standard and test groups. Ten microlitres of standard cholesterol reagent, and samples were added into their respective tubes. They were mixed and allowed to stand for 10 minutes at room temperature. Absorbance of samples and standard were read with the aid of a spectrophotometer at $500 \mathrm{~nm}$. Total cholesterol level in sample was calculated using the formula

Total cholesterol in sample $(\mathrm{mg} / \mathrm{dl})=$ $\frac{\text { Absorbance of sample }}{\text { Absorbance of standard }} \times$ Concentration of standard.

\section{Determination of serum triglyceride}

Serum triglyceride was evaluated according to the methods described by Tietz, (2014). One millilitre $(1 \mathrm{ml})$ of the working triglyceride reagent was added into tubes labelled blank, standard and 
test groups. Ten microlitres of standard triglyceride reagent, and samples were added into their respective tubes. They were mixed and allowed to stand for 10 minutes at room temperature. Absorbance of samples and standard were read with the aid of a spectrophotometer at $500 \mathrm{~nm}$. Total cholesterol level in sample was calculated using the formula;

Total triglyceride in sample $(\mathrm{mg} / \mathrm{dL})=$ $\frac{\text { Absorbance of sample }}{\text { Absorbance of standard }} \times$ Concentration of standard

\section{Determination of serum high density Lipoprotein cholesterol (HDL-cholesterol):}

Serum HDL-cholesterol was evaluated according to the methods developed by National Institute of Health Consensus Development Conference Statement (NIHCDCS). One hundred microliters (100 ul) of samples and standard cholesterol reagent were dispensed into test tubes containing $250 \mathrm{ul}$ of $\mathrm{HDL}$ cholesterol precipitate $(\mathrm{R} 1)$. The mixture was centrifuged at $4000 \mathrm{rpm}$ for 10 minutes. Thereafter, $100 \mathrm{uL}$ of samples and standard supernatants were added to another set of test tubes labelled samples and standard containing cholesterol reagent. The mixture was incubated for 10 minutes at room temperature and absorbance of standard and samples were measured against reagent blank at $500 \mathrm{~nm}$ within 60 minutes using Spectrophotometer. HDL-cholesterol level in sample was calculated using the formula below;
$\mathrm{HDL}$ cholesterol in sample $(\mathrm{mg} / \mathrm{dL})=$ $\frac{\text { Absornaceof sample }}{\text { Absorbance of Standard }} \times$ Concentration of standard.

Determination of serum low density Lipoprotein cholesterol (LDL-cholesterol):

Low density lipoproteins (LDL) cholesterol in serum was calculated using the equation described by Friedewald's et al., (1972). The Friedewald's equation estimates the value of $\mathrm{HDL}-\mathrm{C}$ using the values of total cholesterol, triglyceride and HDL-cholesterol

LDL cholesterol $(\mathrm{mg} / \mathrm{dl})=$ Total cholesterol - $\frac{\text { Triglycerides }}{5}-$ HDL cholesterol.

\section{Estimation of the antioxidant activity}

The methanol leaf extract and fractions of Dennettia tripetala were screened for $\mathrm{DPPH}$ radical scavenging activity according to the method described by [14]. Two millilitre of methanol was added to $0.2 \mathrm{ml}$ of different concentration, 7.81 $15.63,31.25,62.5,125,250,500$ and 1000 $\mu \mathrm{g} / \mathrm{ml}$ of the crude extract and fractions. Then, $0.2 \mathrm{ml}$ of $0.6 \mathrm{mMol}$ of DPPH was added to the mixture. After incubation in the dark for 30 minutes at room temperature, the absorbances of the mixture were measured at $517 \mathrm{~nm}$ against methanol as blank using spectrophotometer. Ascorbic acid was used as a standard and absorbance measurements were done in duplicate. Free radical scavenging activity of the extract and fractions was obtained using the relationship shown below:

$\mathrm{DPPH}$ scavenging activity $=100 \times(\mathrm{AC}-$ AS)/AC)

2020 September Edition | www.jbino.com | Innovative Association 
$\mathbf{A C}=$ Absorbance of control

AS = Absorbance of sample

A graph of percentage inhibition against concentrations of extract and fractions was plotted and the IC50 was extrapolated from regression equation [15].

\section{Statistical Analysis}

Data obtained from the study were analysed with the Statistical Package for Social Sciences (SPSS-20). Results were presented as Mean \pm Standard error of mean (SEM) of sample replicates. Raw data were subjected to one way analyses of variance (ANOVA) followed by post hoc Tukey's test. P-values $<0.05$ was considered to be statistically significant.

\section{Results}

Table I: Comparative Effects of various treatments on serum lipid profile

\begin{tabular}{lccccc}
\hline Treatment & Dose & $\begin{array}{c}\text { Total cholesterol } \\
(\mathbf{m g} / \mathbf{d l})\end{array}$ & $\begin{array}{c}\text { Triglyceride } \\
(\mathbf{m g} / \mathbf{d l})\end{array}$ & $\begin{array}{c}\text { HDL-Cholesterol } \\
(\mathbf{m g} / \mathbf{d l})\end{array}$ & $\begin{array}{c}\text { LDL-Cholesterol } \\
(\mathbf{m g} / \mathbf{d l})\end{array}$ \\
\hline Normal control & $\mathrm{D} . \mathrm{H}_{2} \mathrm{O}$ & $169.93 \pm 6.72$ & $81.96 \pm 2.87$ & $93.77 \pm 4.32$ & $59.77 \pm 10.31$ \\
Diabetic control & $\mathrm{D} . \mathrm{H}_{2} \mathrm{O}$ & $290 \pm 0.79$ & $185.19 \pm 8.88$ & $43.77 \pm 4.69$ & $108.55 \pm 6.65$ \\
Glibenclamide & $\mathrm{D} . \mathrm{H}_{2} \mathrm{O}$ & $176.28 \pm 5.58$ & $127.58 \pm 5.03$ & $87.74 \pm 3.39$ & $63.02 \pm 2.12$ \\
& & & & & \\
Methanol Extract & $250 \mathrm{mg} / \mathrm{kg}$ & $171.72 \pm 2.34$ & $88.38 \pm 3.59$ & $79.31 \pm 2.95$ & $74.74 \pm 2.27$ \\
& $500 \mathrm{mg} / \mathrm{kg}$ & $170.91 \pm 1.71$ & $104.41 \pm 6.14$ & $87.85 \pm 3.93$ & $62.18 \pm 4.85$ \\
Ethyl acetate & $250 \mathrm{mg} / \mathrm{kg}$ & $150.35 \pm 10.37$ & $114.39 \pm 4.19$ & $82.16 \pm 3.60$ & $82.31 \pm 9.75$ \\
fraction & $500 \mathrm{mg} / \mathrm{kg}$ & $164.07 \pm 3.44$ & $133.28 \pm 11.78$ & $66.60 \pm 2.28$ & $70.82 \pm 3.75$ \\
n-hexane fraction & $250 \mathrm{mg} / \mathrm{kg}$ & $175.63 \pm 5.33$ & $119.38 \pm 4.71$ & $85.22 \pm 2.63$ & $66.53 \pm 5.58$ \\
& $500 \mathrm{mg} / \mathrm{kg}$ & $173.35 \pm 0.96$ & $66.64 \pm 5.98$ & $84.57 \pm 1.81$ & $75.46 \pm 0.94$ \\
Butanol fraction & $250 \mathrm{mg} / \mathrm{kg}$ & $175.05 \pm 3.44$ & $83.75 \pm 3.03$ & $81.06 \pm 3.43$ & $95.24 \pm 4.38$ \\
& $500 \mathrm{mg} / \mathrm{kg}$ & $155.89 \pm 6.77$ & $116.89 \pm 8.43$ & $78.43 \pm 2.44$ & $77.08 \pm 7.73$ \\
Water fraction & $250 \mathrm{mg} / \mathrm{kg}$ & $173.35 \pm 0.81$ & $101.92 \pm 3.79$ & $84.57 \pm 1.17$ & $68.40 \pm 2.18$ \\
& $500 \mathrm{mg} / \mathrm{kg}$ & $170.68 \pm 2.85$ & $65.23 \pm 0.91$ & $80.40 \pm 3.93$ & $80.23 \pm 6.18$ \\
\hline
\end{tabular}

Values are presented as mean \pm Standard error of mean (SEM), $n=5$ 
Table II: Effect of various treatments on body weight

\begin{tabular}{cccccc}
\hline Treatments & Dose & $\begin{array}{c}\text { Weight Before } \\
\text { Alloxan } \\
\text { induction }\end{array}$ & $\begin{array}{c}\text { Weight after } \\
\text { Alloxan } \\
\text { induction }\end{array}$ & $\begin{array}{c}\text { Weight After } \\
\text { treatment }\end{array}$ & $\begin{array}{c}\text { Change in } \\
\text { body weight } \\
(\%)\end{array}$ \\
\hline Normal control & D.H ${ }_{2} \mathrm{O}$ & $25.18 \pm 1.33$ & $17.46 \pm 0.67$ & $27.60 \pm 1.21$ & 36.74 \\
Diabetic control & $\mathrm{D} . \mathrm{H}_{2} \mathrm{O}$ & $26.88 \pm 1.64$ & $18.00 \pm 1.05$ & $19.20 \pm 1.07$ & 6.25 \\
Glibenclamide & $5 \mathrm{mg} / \mathrm{kg}$ & $23.72 \pm 3.05$ & $18.06 \pm 1.14$ & $20.20 \pm 2.59$ & 10.59 \\
Extract & $250 \mathrm{mg} / \mathrm{kg}$ & $24.22 \pm 2.87$ & $17.94 \pm 0.73$ & $22.20 \pm 2.63$ & 19.19 \\
& $500 \mathrm{mg} / \mathrm{kg}$ & $28.00 \pm 1.52$ & $17.60 \pm 0.75$ & $24.40 \pm 1.60$ & 27.87 \\
Ethyl acetate fraction & $250 \mathrm{mg} / \mathrm{kg}$ & $30.80 \pm 1.24$ & $18.40 \pm 1.03$ & $27.00 \pm 1.82$ & 31.85 \\
& $500 \mathrm{mg} / \mathrm{kg}$ & $24.40 \pm 2.23$ & $19.00 \pm 1.08$ & $22.20 \pm 2.46$ & 14.41 \\
n-hexane fraction & $250 \mathrm{mg} / \mathrm{kg}$ & $23.60 \pm 1.69$ & $18.74 \pm 0.56$ & $23.60 \pm 1.72$ & 20.59 \\
& $500 \mathrm{mg} / \mathrm{kg}$ & $26.20 \pm 2.89$ & $19.00 \pm 1.58$ & $22.20 \pm 2.15$ & 14.41 \\
Butanol fraction & $250 \mathrm{mg} / \mathrm{kg}$ & $25.80 \pm 1.77$ & $17.60 \pm 0.69$ & $21.80 \pm 1.39$ & 19.27 \\
& $500 \mathrm{mg} / \mathrm{kg}$ & $27.80 \pm 2.40$ & $18.20 \pm 0.66$ & $22.60 \pm 2.84$ & 19.47 \\
Water fraction & $250 \mathrm{mg} / \mathrm{kg}$ & $26.00 \pm 1.61$ & $19.20 \pm 0.66$ & $22.00 \pm 1.58$ & 12.73 \\
& $500 \mathrm{mg} / \mathrm{kg}$ & $28.00 \pm 1.70$ & $18.80 \pm 0.96$ & $22.60 \pm 2.16$ & 16.8 \\
\hline
\end{tabular}

Values are presented as mean \pm Standard error of mean (SEM), $n=5$.

Table III: Comparative Changes of various treatments on Antioxidant Assay

\begin{tabular}{ll}
\hline \multicolumn{1}{c}{ Sample } & IC $_{\mathbf{5 0}}(\mathbf{u g} / \mathbf{m l})$ \\
\hline Methanol Extract & 32.03 \\
N-Haxane fraction & 30.04 \\
Ethyl acetate & 30.05 \\
Butanol fraction & 29.13 \\
Water fraction & 40.16 \\
Ascorbic Acid & 3.00 \\
\hline
\end{tabular}

Figure I: Comparative Effects of various Treatments on Lipid Profile 


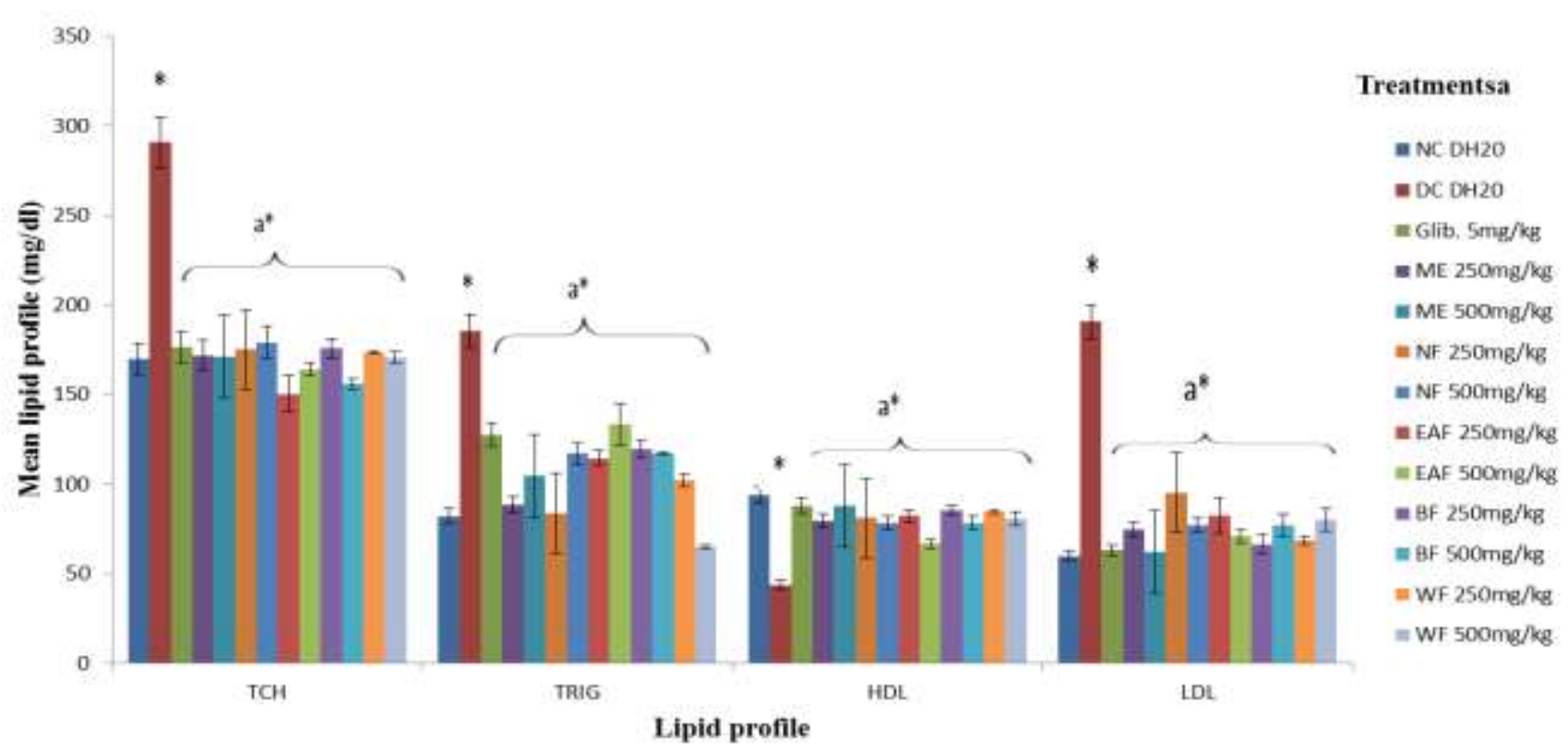

[TCH, TRIG and LDL significantly reduced ( $\left.a^{*} p<0.05\right)$. HDL significantly increased $\left.\left(a^{*} p<0.05\right)\right]$ when compared to diabetic induced (*). Above figure shows the Effect of the oral administration of various treatments on serum Total cholesterol (TCH), Triglycerides (TRIG), Low density lipoproteins (LDL) and High density lipoproteins (HDL). Following daily administration of Methanol extract of Denettia Tripetala and its fractions. NC: Normal control, DC: Diabetic control, ME: methanol extract, NF: N-Hexane fraction, EAF: Ethyl acetate, BF: Butanol fraction, WF: Water fraction and D. $\mathrm{H}_{2} \mathrm{O}$ : Distilled Water.

Figure II: Final Change in body weight of mice for different treatment groups

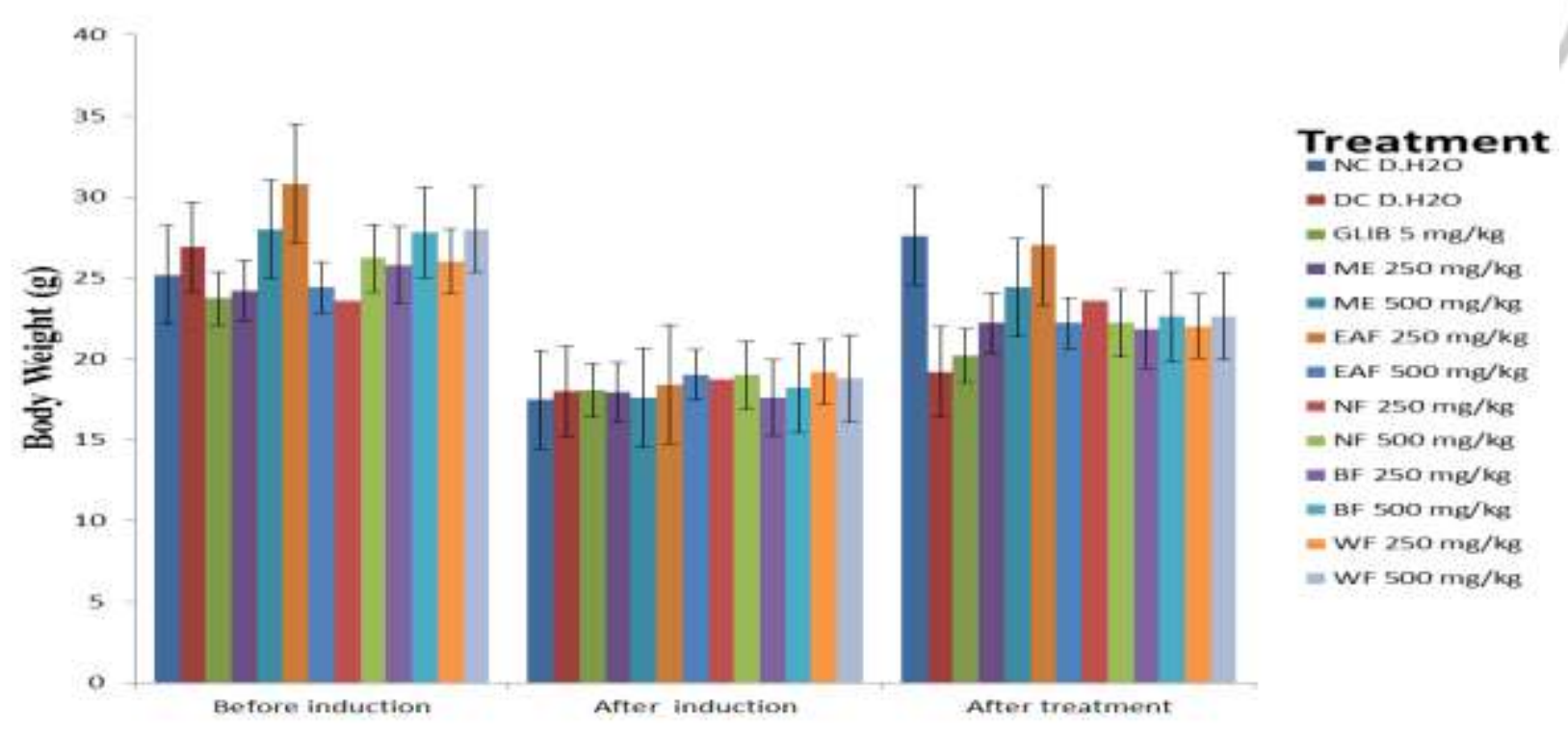

2020 September Edition | www.jbino.com | Innovative Association 


\section{Discussion}

Results from figure I of current study represent the effect of the oral administration of the various treatments on serum total cholesterol, triglycerides, low density lipoproteins and high density lipoproteins. The levels of triglyceride, total cholesterol and LDL-C were significantly elevated and the level of serum HDL-C was decreased in the diabetic control group as compared to normal control. After supplementation with methanol extract and fractions of Dennettia tripetala, the alteration in lipid metabolism were significantly affected as evidenced by decreased serum triglyceride (TG), total cholesterol (TC) and LDL-cholesterol levels and increased HDL cholesterol concentration for both $250 \mathrm{mg} / \mathrm{kg}$ and $500 \mathrm{mg} / \mathrm{kg}$.

Also from current study, diabetic dyslipidaemia was marked by alloxan in diabetic mice by elevated triglycerides, total cholesterol, LDL-C and decreased HDL-C; these constitute important cardiovascular risk factors [14]. These effects may be due to low activity of cholesterol biosynthesis enzymes and or low level of lipolysis which are under the control of insulin [15]. The leaf extract of methanol and fractions Dennettia tripetala supplementation gave significant attenuation in the level of serum lipid profile after supplementation with the leave extract of methanol and fractions Dennettia tripetala.

The alteration in lipid metabolism was significantly attenuated as evidenced by decreased serum triglyceride (TG), total cholesterol (TC), and LDL-cholesterol levels and increased HDL-cholesterol concentration in diabetic mice. Total cholesterol less than $200 \mathrm{mg} / \mathrm{dl}$ is considered to be good. In the present study, the total cholesterol of the untreated mice was $290 \mathrm{mg} / \mathrm{dl}$. The extract and fractions of DT was considered effective since it was able to cause a remarkable reduction when compared to the diabetic control group and the standard drug Glibenclamide. $250 \mathrm{mg} / \mathrm{kg}$ Ethyl acetate fraction was considered to cause the highest reduction $(150.35 \mathrm{mg} / \mathrm{dl})$. $500 \mathrm{mg} / \mathrm{kg}$ of Butanol fraction was considered to next in the reduction rate with a value of $(155.89 \mathrm{mg} / \mathrm{kg})$. The least in the order of reduction rate was $\mathrm{N}$-hexane fraction $250 \mathrm{mg} / \mathrm{kg}$ with a value of $(175.63 \mathrm{mg} / \mathrm{dl})$. Triglyceride less than $149 \mathrm{mg} / \mathrm{dl}$ is considered to be good. 
For TG, water fraction had the lowest reduction rate with a value of $(65.23 \mathrm{mg} / \mathrm{dl})$. This result was followed by $\mathrm{N}$-hexane fraction $500 \mathrm{mg} / \mathrm{kg}$, with a value of $(66.64 \mathrm{mg} / \mathrm{dl})$ and the least was Ethyl acetate fraction $500 \mathrm{mg} / \mathrm{kg}$ with a value of $(133 \mathrm{mg} / \mathrm{dl})$. HDL-Cholesterol above, $40-45$ is considered to be good. From results obtained from HDL-C, $500 \mathrm{mg} / \mathrm{kg}$ methanol extract had the highest increase compared to the other fractions, with a value of $(87.85 \mathrm{mg} / \mathrm{dl})$.

This result was followed by $\mathrm{N}$ hexane $250 \mathrm{mg} / \mathrm{kg}$ with a value of $(85.22 \mathrm{mg} / \mathrm{dl})$ and the least was Butanol $500 \mathrm{mg} / \mathrm{kg}$ with a value of $(78.43 \mathrm{mg} / \mathrm{dl})$. LDL- cholesterol less than $100 \mathrm{mg} / \mathrm{dl}$ is considered to be good. Butanol fraction $250 \mathrm{mg} / \mathrm{kg}$ shown to have the highest reduction rate with a value of (95.24mg/dl), followed by Ethyl acetate $250 \mathrm{mg} / \mathrm{kg}$ with a value of $(82.16 \mathrm{mg} / \mathrm{dl})$ and the least was methanol $500 \mathrm{mg} / \mathrm{kg}$ with a value of $(62.18 \mathrm{mg} / \mathrm{dl})$. The findings are in agreement with Kaleem and others who revealed that ethanoic extract of Nigella sativa seeds produced significant decreased in serum lipid profile (total cholesterol, LDL- C and triglyceride) and increased HDL-cholesterol level [16].
Similar findings were reported on Raphia hookeri seed extract on diabetic rats [17]. According to Luo et al, 2013, Mayilvaganan et al., 2014 and Ogbunugafor et al., 2012 reported that various doses of ethanol extract of Cajanus cajan showed a significant $(P<0.05)$ increase in the level of high density lipoprotein cholesterol (HDL - C) and significant $(\mathrm{p}<0.05)$ decrease in total cholesterol (TC), low density lipoprotein cholesterol (LDL - C) and triacylglycerol after four weeks of treatment in albino rats. The results which correspond to the reports of Luo et al, 2013 also revealed a significant (<0.05) decrease in the level of triacylglycerol and thus infer the importance of the extract in weight and cardiovascular risk management. Offor et al., 2014 earlier reported that total cholesterol, triacylglycerol and LDL-cholesterol levels were significantly $(\rho<0.05)$ reduced by ethanol leaf-extracts of Vernonia amygdalina and Azadirachta indica while HDL-cholesterol levels were increased significantly. Aja et al., (2015) reported no significant $(P<0.05)$ increase in total cholesterol (TC), high density lipoprotein cholesterol (HDL - C) and low density lipoprotein - cholesterol (LDL - C) 
levels in rats administered ethanol extract of Cajanus cajan leaves.

High blood cholesterol concentration is one of the important risk factors in heart disease [17]. Thus, the reduction in serum total cholesterol concentration produced by the extract is beneficial and may reduce the risk of cardiovascular disease because agents that have been reported to function. Elevated HDL-C is very significant in human health because it improves the transportation of cholesterol from plasmas to the liver for biotransformation and excretion, thereby preventing asthma formation and blood vessel occlusion [18]. In support of this study other studies had reported a significant change in lipid profile parameters following induction of diabetes with alloxan monohydrate [19\&20].

\section{Conclusion}

From current study, after supplementation with the leaf extract of methanol and fractions Dennettia tripetala, the alteration in lipid metabolism was significantly attenuated as evidenced by decreased serum triglyceride (TG), total cholesterol (TC), and LDL-cholesterol levels and increased HDL-cholesterol concentration in diabetic mice.

\section{References}

1. Aja, P.M., V.I., Ibekwe, E.U., Ekpono. Ugwu, P.C. and Okechukwu, (2015). Effect of Ethanol extract of cajanus cajan leaf on plasma lipid level in albino rats. International Journal of Current Research and Academic Review, 3(1): 161-167

2. Akah, P.A. and Okolo, C.E. (2011). Antidiabetic activity of aqueous and methanol extract and fractions of Gongronema latifolium (Asclepidaceae) leaves in Alloxan Diabetic Rats. Journal of Applied Pharmaceutical Science 01 (09); 99-102.

3. Akah, P.A., Okoli C.O., Ibiam, A.F., Ezike A.C and Okoye T.C. (2010). Evaluation of antidiabeticpotentials of Phyllanthus niruri in alloxan diabetic rats. Africa Journal of Biotechnology, 9:248-259.

4. Akah, P.A., Okoli, C.O., and Nwafor, S.V. (2002). Phytotherapy in the management of diabetes mellitus. Journal of Natural. Remedies 2 (1): 1-10

5. Akinbuluma, M. D., Adepetun, M. T. and Yeye, E. O. (2015). Insecticidal Effects of Ethanol Extracts of Capsicum Frutescens and Dennettia Tripetala against Sitophilus Zeamais Motschulsky on Stored Maize. International Journal of Research in Agriculture and Forestry.2, 11. 1-6. 
6. Barbosa-Filho, J.M., Vasconcelos, T.H.C., Alencar, A.A., and Bartista L.M. (2005). Plants and active constituents from South, central and North America with hypoglycemic activity. Brazilian. Journal of Pharmacognosy 15 (4): 392-413.

7. Momoh, Johnson, Longe, Adeteju, Olufunmilayo,Campbell, Charles Adegboyega and Omotayo Mutiat Adetayo, (2014). Evaluation of Antidiabetic and the Effect of Methanolic Leaf Extract of Jatropha curcas on Some Biochemical Parameters in Alloxaninduced Diabetic Male Albino Rats. European Journal of Medicinal Plants4(12): 1501-1512.

8. Lorke, D. (1983). A new approach to practical acute toxicity. Archives of Toxicology. 53:275-289.

9. Neharkar, V.S. and Gaikad, K.G. (2011). Hepatoprotective activity of Cassia alata (linn) leaves against paracetamol induced hepatic injury in rats. Research Journal of Pharmaceutical, Biological and Chemical Sciences. 2(1):783-788.

10. Chiasson, J.L., Josse, R.G. and Gomis, R. (2012). Stop-niddm Trail Research Group. Aiarbose for prevention of type 2 diabetes mellitus: Lancets 359: 2072-2077

11. Cho N.H., Shaw, J.E., Karuranga S, Huang, Y., da Rocha Fernandes, J.D, Ohlrogge, A.W, Malanda, B.(2018). Global estimates of diabetes prevalence for 2017 and projections for 2045. IDF Diabetes Atlas: 138:271-281
12. College of Veterinary Medicine, Washington State University. (2009). Diabetes Mellitus. Retrieved online at http://www.vetmed.wsu.edu/client ed/diabetes. aspx on 23-12- 2009.

13. Tietz, N.W. (2014). Clinical guide to Laboratory tests, Second edition W.B. Saunders Company, Philadelphia, USA 554-556.

14. Concannon, P., Gogolin-Ewens, K.J., Hinds, D.A., Wapelhorst, B., Morrison, V.A and Stirling B (2013). A second generation screen of the human genome for susceptibility to insulin-dependent diabetes mellitus. Nature Genetics: 19: 292296.

15. Elliott, R.B., Pilcher, C.C., Fergussion, D.M. and Stewart, A.W. (2013). A population based strategy to prevent insulin dependent diabetes using nicotinamide. Journal Pediatrics Endocrinology Metabolism 9 (5)501-509

16. World Health Organization (2016). Global Report on Diabetes. NLM classification 810. Geneva.

17.Ezeigho, I. 2016. Antidiabetic potential of methanolic leaf extracts of lcacina trichantha in alloxan-induced diabetic mice. International Journal of Diabetes in Developing Countries.

18. Walley, A.J., Blakemore, A.I. and Froguel, P. (2006). Genetics of Obesity and the predication of risk for health. Human Moleclar Genetics. 15 (2): 124-130. 
19. Wasko, M.C., Hubert, H.B. and Lingala, V.B. (2007). Hydroxychloroquine and risk diabetes in patients with rheumatoid arthritis. Journal of the America Medical Association 298 (2) 187-193.

20. Ihekwereme, C. P., Chukwuson, M.A., Erhirhie, E.O and Uche, G. O. (2016). Preliminary evaluation of the Anti-Emetic activity of crude methanol extract and fraction of Ocimum gratissimum. Journal of Developing Drugs. 5 (1): 2329-2331

21. Weyer, C., Bogardus, C, Mott, D.M, and Pratley, R.E (2014). The natural history of insulin secretary dysfunction and insulin resistance in the pathogenesis of type 2 diabetes mellitus. Journal of Clinical Investigation 104: 787-794. 